http://dx.doi.org/10.18778/8088-239-3.12

ELEONORA JEDLIŃSKA

Katedra Historii Sztuki

Uniwersytetu Łódzkiego

\title{
NAMIĘTNOŚCI DUCHA, CZYLI SZTUKA NARODOWA NA POWSZECHNEJ WYSTAWIE ŚWIATOWEJ W PARYŻU W 1900 R.
}

W ystawa 1900 r. była swoistą paradą prezentującą utopijną wizję ogólnej harmonii między narodami i państwami w świecie egzystującym bez wrogów i konfliktów. Pamiętajmy wszak, że XIX w. był eksplozją poszukiwania i odnajdywania narodowych identyfikacji, walki o niezależność narodów wchłoniętych przez potężne gospodarczo i militarnie państwa, kolonizacji świata i agresywnego europocentryzmu.

Powszechne w tamtym czasie było przekonanie, że wobec Francji cały cywilizowany świat ma dług, ponieważ właśnie ten kraj był u swych początków źródłem kultury, nauki, „tchnął namiętności i impuls życia w stary świat”, jak pisał w latach dziewięćdziesiątych XIX w. angielski arystokrata sir Almeric William Fitzroy (1851-1935), sekretarz diuka Devonshire. Dramat przełomu Wielkiej Rewolucji Francuskiej powrócił ze szczególną mocą w latach 1897-1899, kiedy to Francja, rozdarta wewnętrznymi emocjami, wyzwalającymi zadawnione konflikty, wprowadzającymi rozłam w społeczeństwie, angażując potencjał myśli, energię i dumę Francuzów, pogrążyła się w chaosie, jednym z najdramatyczniejszych w historii ${ }^{1}$. Leon Blum, wówczas dwudziestokilkuletni, przyszły premier Francji (w latach 1936-1937, 1938, 1946-1947), żywo zaangażowany w tzw. sprawę Alfreda Dreyfusa, która „wprowadziła” go w świat polityki, pisał:

Przez te dwa niekończące się lata walki o uzyskanie rewizji procesu jednego niewinnie skazanego człowieka, życie zostało jakby zawieszone. Było to tak, jakby w latach wzburzenia, prawdziwej wojny domowej [...] wszystko skupiło się na jednej jedynej sprawie, jakby wszystko w najintymniejszych uczuciach

${ }^{1}$ Por. B.W. Tuchman, Wyniosła wieża. Świat przed pierwszq wojnq światowq 1890-1914, tłum. J. Zawadzka, Warszawa 1966, s. 215 i nast. 
i osobistych stosunkach zostało przerwane, odwrócone do góry nogami, przeklasyfikowane [...] Sprawa Dreyfusa stała się kryzysem społeczeństwa [...] $]^{2}$.

Skazanie oficera armii francuskiej - Żyda za zdradę na rzecz Niemiec (jak się okazało w wyniku rozstrzygnięć ostatecznie wznowionego procesu - człowieka niewinnego) nabrało wymiaru ostatecznej walki o sprawiedliwość. Jedni toczyli batalię o wznowienie procesu, inni - o powstrzymanie wszelkich działań.

Społeczeństwo francuskie dekadencję końca wieku zostawiło pięknoduchom, samo pogrążając się z jednej strony w aktach ofiarności, bezinteresowności i odwagi, z drugiej - nienawiści, strachu, ksenofobii i zła. Kierując się szlachetnymi pobudkami, skonfliktowane frakcje (zwolenników niewinności A. Dreyfusa i przeciwników, zwolenników rewizji skazującego procesu sądowego i przeciwników tej weryfikacji) ścierały się z sobą w przekonaniu, że od tej bitwy zależą losy republiki. Oba obozy walczyły o własną wizję Francji - pierwsza o Francję kontrrewolucji, druga o Francję 1789 r.;

jedna o swą ostateczną szansę zahamowania postępowych tendencji społecznych i przywrócenia dawnych wartości; druga o oczyszczenie honoru republiki i uchronienie jej od szponów reakcji ${ }^{3}$.

Trzecia Republika, postrzegana jako źródło wolności, kraj oświecenia, cywilizacji, równości i braterstwa, ustawodawcy prawa w oczach tych, którzy oczekiwali uniewinnienia skazanego za domniemaną działalność szpiegowską A. Dreyfusa, przede wszystkim chcieli sprawiedliwości. Francja nacjonalistów, twierdzących, że toczą bitwę w imieniu ojczyzny o zachowanie armii jako przedmurza i opiekunki narodu, oraz Kościoła jako orędownika i przewodnika domagała się „oczyszczenia honoru republiki i uchronienia jej od szponów reakcji”"4. Około 1900 r. idee nacjonalistyczne rozbrzmiewały w całej Europie, potęga Rosji i Prus, wzrastająca siła zjednoczonych Niemiec, dążenia niepodległościowe państw wchłoniętych przez ówczesne potęgi, wyzwalające chęć walki o własną przynależność narodową, przekształcały Europę w przepełniony namiętnościami wrzący tygiel zarzewia nadciągającej katastrofy. Francuski rząd mimo zewnętrznego dobrobytu czuł się słaby, w obliczu międzyspołecznego konfliktu rodaków stanął po stronie swych domniemanych przeciwników. Był to rząd niepewny, niecieszący się powszechnym zaufaniem, lekceważony i defensywny.

\footnotetext{
2 Ibidem.

${ }^{3}$ Ibidem, s. 216.

${ }^{4}$ Ibidem.
} 
Dwa razy od 1789 roku - pisze B.W. Tuchman - republika musiała ustąpić odradzającej się monarchii. Wynurzywszy się po roku 1871 jako Trzecia Republika, Francja odżyła, rozkwitła, stała się imperium ${ }^{5}$.

Ta Francja troszczyła się o rozwój sztuki, była internacjonalistyczna, szczyciła się najpełniej rozwiniętą i najświetniejszą kulturą, stanowiła wzór dla świata. Paryż ze swymi muzeami, galeriami, atelier i szkołami artystycznymi był miastem otwartym dla najnowszych tendencji twórczych tamtego czasu, stolicą sztuki, do której pielgrzymowali młodzi malarze z całego świata - i wszyscy malowali tak, jak nauczali francuscy mistrzowie sztuki. W 1889 r., w rocznicę wybuchu Wielkiej Rewolucji Francuskiej, wzniesiona została w Paryżu najwyższa budowla świata - zuchwała, wspaniała wieża Eiffla. Stała się symbolem geniuszu i energii życiowej Francji.

W życiu politycznym, od wewnątrz, naród zmagał się z własną przeszłością, z niezadowoleniem nadal próbu-

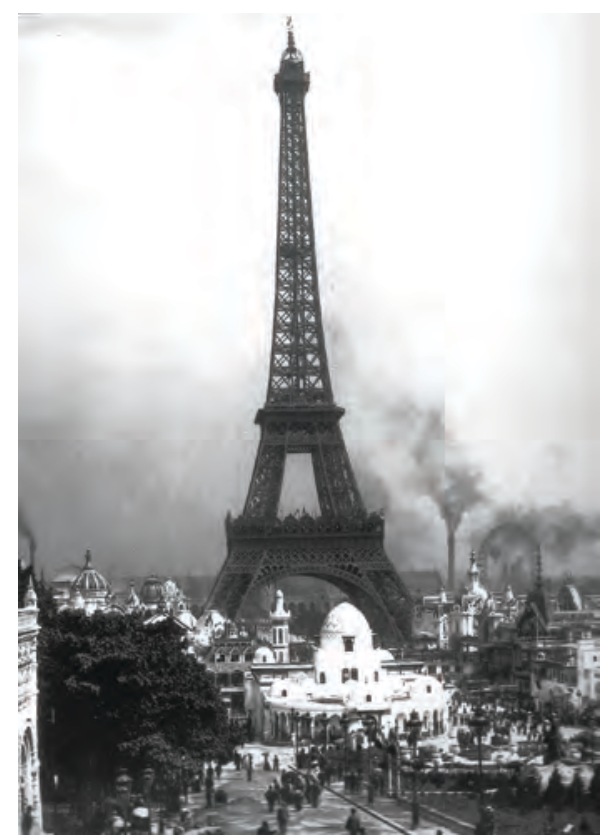

Ryc. 12. Panorama Paryża w 1900 r. z wieżą Eiffla jących powrócić zwolenników ancien régime'u i Drugiego Cesarstwa; od zewnątrz niepokojony przez dominującą siłę Niemiec i świadomość niezakończonej wojny z tym mocarstwem w latach 1870-1871, domagał się zadośćuczynienia. Sfrustrowana prawica, niezadowolona, odsunięta arystokracja, rojaliści, Kościół, familie wielkich interesów w tym samym 1889 r. próbowały dokonać pod wodzą generała Georges’a Boulangera (1837-1891) zamachu stanu, który zakończył się przegraną. Nastroje nacjonalistyczne zdawały się sięgać wyżyn w obliczu wydarzeń poprzedzających katastrofę, jaką miały przynieść kolejne lata.

Tłem Powszechnej Wystawy Światowej w Paryżu w 1900 r. były: industrializacja, narastające na świecie nastroje patriotyczno-nacjonalistyczne, militaryzm, gwałtowny rozwój wielkich aglomeracji, upadek wsi, wzrastająca potęga pieniądza i maszyny, frustracja robotników, schyłek arystokracji, nasilenie antysemityzmu. Wszystkie te moce zdawały się wrzeć z niepokoju, w oczekiwaniu na wielki wybuch, który byłby zdolny je uwolnić.

\footnotetext{
${ }^{5}$ Ibidem, s. 217.
} 
Powszechna zabawa, ów wielki jarmark, jakim była wystawa 1900 r., jawił się jako próba chwilowej ucieczki przed dramatem przemocy, od którego świat dzieliło 14 lat niejasnego przeczucia, że dawny, kosmopolityczny, oparty na własności porządek agrarno-feudalny umarł.

Na przełomie stulecia odczuwano lęk, ,jakby karta ludzkiego losu obrócona została ręką Boga"6. Dobrodziejstwa cywilizacji, postęp, energia mechaniczna, dobra materialne stawały się coraz bardziej dostępne, ale jednocześnie stawiano sobie pytanie, czy w istocie są to dobrodziejstwa? Czy i jakie zagrożenia są ich udziałem? Na wystawie światowej w 1900 r. wprawdzie sztuce przyznano miejsce w okazałych budowlach Grand i Petit Palais, lecz Niemcy obok porcelany, srebra, najcieńszego szkła, najlepszego malarstwa demonstrowały działa o dalekim zasięgu i szybkostrzelne karabiny maszynowe.

Ochroną przed tym strachem wydawał się zwrot ku poszukiwaniu własnego narodu, tożsamości, korzeni sięgających dalekiej przeszłości. Sztuka stała się ekranem tych obaw i złych przeczuć, na którym można było rozpoznać, gdzie tkwią tłumione namiętności zwycięzców i pokonanych, szczęśliwców reprezentujących własne państwa i tych, którzy o prawo do samostanowienia swojej nacji walczyli.

$$
* * *
$$

Z dzisiejszego punktu widzenia aspekt narodowy w istocie był jednym z najważniejszych problemów, którego zwierciadłem była ekspozycja sztuki w Grand Palais. Autorzy opracowania 1900. Art at the Crossroads przywołują obraz Kupiec i jego rodzina w XVII wieku (1896) Andrieja Rabuszynskiego, jednego z 283 malarzy rosyjskich pokazujących swe prace w Paryżu. Twórca przedstawił bogatą rodzinę rosyjskiego kupca, której euroazjatyckie korzenie uwidocznione są w charakterze wnętrza (będącego kombinacją tradycji azjatyckich i europejskich) oraz strojów sportretowanych osób. Hieratyczne twarze postaci inspirowane są wizerunkami świętych przedstawianych na ikonach. Matka trzymająca na kolanach dziecko przypomina wizerunki Matki Boskiej Hodigitrii ${ }^{7}$.

Poszukiwanie i umacnianie narodowych tożsamości było zjawiskiem dominującym w XIX w. Jego tło stanowiło powstawanie jednonarodowościowych państw, wojny, powstania narodowe, ekonomiczna i mocarstwowa rywalizacja oraz nacjonalizm. Sztuka stała się narzędziem promocji ideologii narodowych. Państwo otaczało kulturę opieką - literatura uchodziła za sztukę wiodącą, kształtującą duchowość i światopogląd społeczeństw

${ }^{6}$ Ibidem, s. 333.

7 R. Rosenblum, M.A. Stevens, A. Dumas, 1900. Art at the Crossroads, 16 January - 3 April 2000 [katalog wystawy, Solomon R. Guggenheim Museum], New York 2000, s. 11. 
XIX w. Do artystów należało przełożenie na obraz (dzieło) owych przewodnich koncepcji literacko-pojęciowych. Mieli więc określone zadania do wypełnienia i często robili to z upodobaniem. Sale wystawowe pełne były pejzaży i przedstawień pokazujących lokalne tradycje czy sceny mitów narodowych wpisanych we współczesną rzeczywistość. „Wystawa Powszechna i Wystawa Dziesięciolecia umożliwiły zbudowanie trybuny dla narodowych sentymentów"8. Uszeregowane wzdłuż Quai des Nations pawilony narodowe tworzyły miasto zbudowane z żeliwa i gipsu; zbiorowisko tymczasowych budynków powstałych po to, by propagować charakterystyczne dla danego państwa cechy architektoniczne, dające się utożsamić z tym państwem i reprezentujące rozpoznawalne zdobycze każdego z krajów. Podczas Wystawy Powszechnej w 1889 r. akcentowano prezentację najświetniejszych osiągnięć współczesnej architektury, natomiast wystawa w 1900 r. przede wszystkim reprezentowała siebie jako apoteozę tożsamości narodowej, czyniąc to za pomocą odniesień do historycznych wzorów. Podkreśleniu narodowej identyfikacji służyła architektura pawilonów poszczególnych nacji i tematyka dzieł prezentowanych na wystawach. Mity narodowe inspirowały prace artystów z Francji, Anglii, Szwecji, ziem fińskich, islandzkich i polskich.

Chłopi w strojach narodowych zapełniali płótna rosyjskich, szwedzkich, polskich, duńskich, węgierskich, francuskich i niemieckich artystów; sceny rodzajowe były łatwo rozpoznawalne i także służyły podkreśleniu cech narodowych, nawet gdy posługiwano się tak modnym wówczas stylem japońskim przefiltrowanym przez styl pseudozachodni ${ }^{9}$.

Nastroje nacjonalistyczne towarzyszyły artystom, którzy wywodzili się z krajów walczących o swą niezależność (np. Finlandia, Polska, Litwa, Estonia, kraje bałkańskie itd.), a także tym, którzy reprezentowali państwa ciszące się stabilną sytuacją geopolityczną. Fiński malarz Akseli Gallén-Kellela (1865-1931), autor fresków do pawilonu prezentującego jego ojczyznę, przedstawiających sceny odnoszące się do sytuacji politycznej Finlandii, zależnej od Imperium Rosyjskiego, w ramach wystawy w Grand Palais pokazał obraz tematyką odwołujący się do fińskiego eposu narodowego Kale$v a l{ }^{10}$. Twórczość A. Gallen-Kalleli przypadła na szczególnie ważny moment

\footnotetext{
${ }^{8}$ Ibidem, s. 62.

${ }^{9}$ Ibidem, s. 63.

${ }^{10}$ Kalevala - zbiór tzw. pieśni runicznych, poezji przekazywanej ustnie, stanowiącej częściowo historyczny, częściowo legendarny epos spisany przez Eliasa Lönnrota, wydany w $1849 \mathrm{r}$. Opowiada o bohaterach żyjących w mitycznej krainie Kalevie (obecna Karelia). Kalevala stała się dla Finów źródłem ich historii, języka i mitów, odmiennych od kultury Szwedów i Rosjan. Por. E. Lönnrot, Kalevala, tłum. J. Litwiniuk, Warszawa 1998.
} 
w historii Finlandii. Przełom XIX i XX w. był także dla jego kraju czasem kształtowania się narodowej tożsamości, okresem poszukiwania odrębności i wyjątkowości własnej kultury. Artysta wywodził swą twórczość z realizmu. W 1884 r. wyjechał do Paryża na studia w Académie Julian (do 1889 r.) i - zapoznawszy się ze współczesnymi tendencjami sztuki, takimi jak symbolizm, ekspresjonizm, secesja - przekształcił swe malarstwo, nadając mu z jednej strony cechy typowe dla dzieł modernizmu końca XIX w., z drugiej - nasycając je elementami związanymi z tradycją i kulturą fińską. Po latach zmagania się ze zilustrowaniem Kalevali przeszedł drogę od akademizmu do stylu dekoracyjnego, dzięki któremu mógł wyrazić mitologiczny aspekt eposu. Zyskał pozycję artysty głęboko związanego z tradycją i kulturą swego narodu, a zarazem tworzącego odrębny, własny styl. W roku 1890 Gallen-Kallela wrócił do Finlandii i zamieszkał w zaprojektowanym przez siebie domu w Ruovesi ${ }^{11}$. Tu powstały kolejne obrazy cyklu Kalevali, ich konwencja stylistyczna wskazywała niezależność wobec tendencji poznanych i przyjętych w czasie studiów w Paryżu. Niemniej owo monumentalne malarstwo bliskie jest poszukiwaniom Pierre’a Puvisa de Chavannes'a (1824-1898), posługującego się uproszczoną warstwą malarską wyobrażenia postaci i przedmiotów obrysowywanych mocnym konturem, linearnością, płaskością - są to wyraźnie cechy znamionujące sztukę francuskiego symbolisty. Te cechy znalazły oddźwięk w dziełach wielu artystów końca XIX i początku XX w. Malarstwo to fascynowało także A. Gallen-Kallelę - na wystawie w Paryżu w 1900 r. pokazał on obraz Matka Lemminkäinena (1897) przedstawiający scenę ilustrującą historię jednego z bohaterów Kalevali - moment, gdy matka (do obrazu pozowała matka malarza) scala poćwiartowane zwłoki syna i przywraca mu życie. Jest to symboliczne wyobrażenie jednego z epizodów oralnej legendy opowiadającej o prehistorii fińskiego ludu: śmierci i wskrzeszeniu poety Lemminkäinena. Jego ciało leży pośród porzuconych czaszek, fragmentów ludzkich kości, na zbroczonym krwią kamienistym brzegu rzeki Tuoneli, gdzie chciał zgłębić tajemnicę wiecznego życia. Według mitu tajemnicy Królestwa Śmierci strzeże biały łabędź; tylko uśmiercenie dumnego ptaka umożliwiłoby wykradzenie sekretu życia po śmierci. Pozornie realistyczny obraz, z dokładnie odtworzonym przez artystę każdym detalem, jest ucieleśnieniem mistycznego symbolizmu. Matka wpatruje się w schematycznie wyobrażone promienie słońca, otwarta puszka na żywiczne balsamy do namaszczania ciała, sugerująca jej pierwotne pogodzenie się ze śmiercią dziecka, kontrastuje z wyobrażeniem białych pąków krokusów (?), symbolizujących odrodzenie i tlącą się w jej sercu

${ }_{11}$ Por. K. Varnedoe, Northern Light, New Haven, London 1988, s. 90; P. Wageman, Fired by Passion. The life and work of Akseli Gallen-Kallela, [w:] Akseli Gallen-Kallela. The spirit of Finland, red. D. Jacobson. P. Wageman, Rotterdam 2007, s. 10-21; W. Król, Między realizmem 
nadzieję, że syn powstanie z martwych. Kobieta wysyła ku słońcu pszczołę, by zebrała nektar ze „źródła promieni goryczy” - z kamienistej ziemi pośród wątłych białych pąków, wokół martwego ciała mężczyzny wynurzają się chorobliwe czarne kwiaty ${ }^{12}$. Twórca wykorzystuje cechy charakterystyczne dla malarstwa symbolistycznego, bliskiego właśnie P. Puvisowi de Chavannes'owi, łącząc pogański mit z tradycją ikonografii chrześcijańskiej (matka opłakująca syna). Posługuje się stylistyką typową dla secesji: ujęciem dekoratywnym, monumentalnymi, uproszczonymi formami, wyrazistymi konturami, płaskością, jasną, lecz przygaszoną gamą kolorów. Głównymi motywami tego obrazu są śmierć, miłość matki i tajemnica życia, ucieleśniona w postaci białego łabędzia pływającego po wodach Tuoneli, mitycznej rzeki świata umarłych.

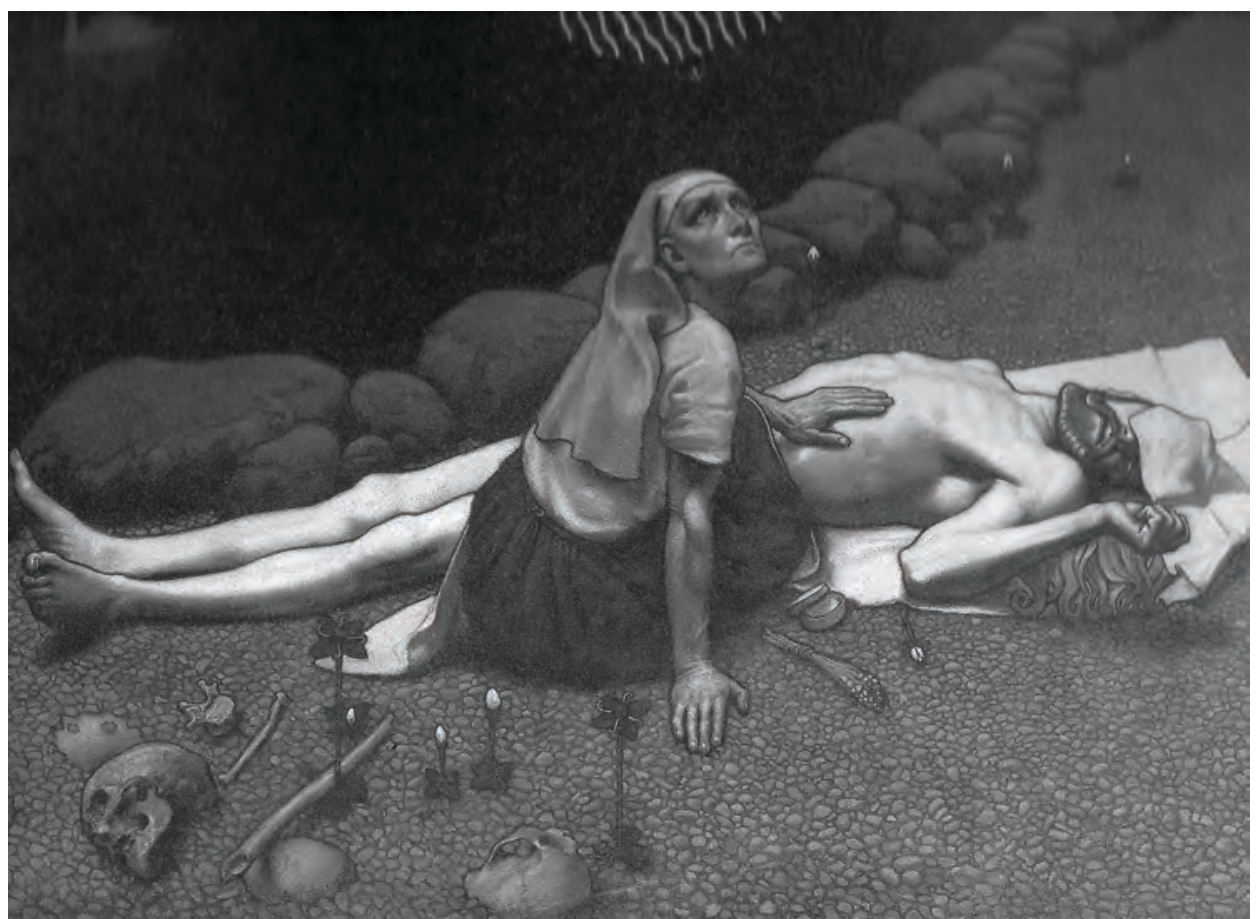

Ryc. 13. Akseli Gallen-Kallela, Matka Lemmikäinena, 1897

Choć przez polityków Finlandia i Rosja na wystawie 1900 r. traktowane były jako jedna sekcja, to wyraźnie zainteresowanie krytyków i publiczności skupiło się na obecności Finów. Architekturę fińskiego pawilonu

a symbolizmem. Twórczość Akseli Gallen-Kalleli, 2009, http://www.kul.pl/files/564/public/ ARTykuly/ARTykuly003/ARTykuly_003_2009_WK_23str.pdf (dostęp: 19.01.2016).

12 Por. S. Sarajas-Korte, Lumière du Nord [katalog wystawy, Petit Palais], Paris 1987, s. 124. 
ozdobionego malarstwem A. Gallen-Kalleli, fińskie rzemiosło, obrazy Pekki Halonena (1865-1933), Rabbego Enckella i Eero Järnefelta (1863-1937) przedstawiano jako przykłady sztuki odpowiadającej najnowszym tendencjom współczesności, z talentem i smakiem łączącej cechy narodowe z najlepszymi osiągnięciami sztuki francuskiej XIX w. Znamiennym jest to, że Finowie odnaleźli w malarstwie P. Puvisa de Chavannes’a źródło własnych poszukiwań twórczych, przesycając przy tym własną sztukę niepowtarzalnym klimatem i realiami Północy ${ }^{13}$. Halonen eksponował płótno Pranie w przeręblu (1900), E. Järnefelt Palenie chrustu (1893) - obrazy wyobrażające życie ubogich mieszkańców Finlandii, zmagających się z surowym klimatem i trudami codziennej egzystencji.

Bywało, że mniej uważni obserwatorzy - jak zaznaczono wyżej - łączyli sztukę fińską z rosyjską, co również wynikało z faktu, że artyści fińscy często studiowali w Akademii Sztuk Pięknych w Petersburgu, a to wpływało na styl i formę ich malarstwa. I jakkolwiek wystawę sztuki fińskiej uważano za ciekawszą i bardziej oryginalną, doceniono rolę sztuki rosyjskiej, podkreślając odrębność narodową obu nacji i kładąc nacisk na mistrzostwo takich twórców rosyjskich jak Ilja Repin (1844-1930), Walentin Sierow (1865-1911), Filipp Andreevich Malyavin (1869-1940). Na tle innych artystów rosyjskich ich dzieła wprawdzie wyróżniały się nowatorskim podejściem do malarstwa, lecz nadal w impresjonizmie znajdowali miejsce dla swej wizji sztuki nowoczesnej. Rosjanie pokazali w Paryżu kilkaset dzieł swoich artystów - były to akademicko doskonałe realistyczne obrazy, wpisujące się tematyką w ideologię demonstrowania przynależności narodowej, tak znamiennej dla etosu wystawy powszechnej w Paryżu w 1900 r. Malarze z upodobaniem podejmowali motywy odnoszące się do historii Rusi, przedstawiali wiejski folklor i obyczaje ludu rosyjskiego - wątki zawsze dla Zachodu atrakcyjne. Na tym tle wyróżniała się twórczość Isaaka Lewitana (1860-1900), rosyjskiego malarza pochodzenia żydowskiego, który pokazał bliski poszukiwaniom impresjonistów obraz Jesienny dzień. Sokolniki (1879). Sierow zaprezentował piękny portret Wiery, dwunastoletniej wówczas córki przyjaciela i kolekcjonera sztuki Sawwy Mamontowa (Dziewczyna z brzoskwiniami, 1887). Krytyka zwróciła uwagę na impresjonistyczne, bliskie dociekaniom Auguste’a Rodina rzeźby Pawła Trubieckiego (1866-1938), który zdobył Grand Prix. Taką samą nagrodę otrzymał Mark Antokolski (1842-1902) ${ }^{14}$ za rzeźby Pax oraz Uśpione piękno.

13 Por. B. Guinaudeau, La Décennale russe, „L'Aurore”, 27.07.1900.

14 Mark Antokolski reprezentował Rosję, ale korespondenci prasowi i krytycy (Antoni Potocki, Liebekowa) polscy włączali go do rozproszonej w różnych pawilonach reprezentacji polskich artystów. 


\section{Bernard Guinaudeau pisał:}

Artyści rosyjscy potrafią wyrazić siłę, urok i piękno swego kraju, skupić naszą uwagę na portretach myślicieli, ludzi aktywnych, na obrazach wyobrażających kobiety i dziewczyny malowanych w sposób miękki i melancholijny, rozległych panoramach stepów i tajgi ${ }^{15}$.

Rzeźbiarz M. Antokolski, urodzony w Wilnie w ubogiej rodzinie żydowskiej, reprezentował Rosję, zapewne język i kultura rosyjska były mu bliższe niż dziedzictwo polskie. Jerzy Malinowski zwraca uwagę, że żydowskie środowisko Wilna oraz litewsko-ruskich ziem wschodnich dawnej Rzeczypospolitej (zachodnich guberni Cesarstwa), w związku z rusyfikacją administracji, szkolnictwa oraz - po 1864 r. - zakazem druku w języku polskim i używania tego języka w miejscach publicznych, stopniowo przyswajało sobie język rosyjski i rosyjskie obyczaje, co dawało możliwość awansu. Po latach samodzielnej nauki rzemiosła artystycznego i pracy w warsztatach snycerskich, w roku 1862, na dwa miesiące przed wybuchem powstania styczniowego, z listem polecającym od A. Nazimowej, żony wileńskiego generała-gubernatora, wyjechał do Petersburga, by studiować w Akademii Sztuk Pięknych ${ }^{16}$. Rzeźby M. Antokolskiego pod względem tematyki i przesłania ideologicznego związane są zarówno z kulturą żydowską, jak i rosyjską. Tworzył dzieła historyczne, przedstawienia władców Rosji i dawnych osobistości (np. Iwana Groźnego - 1871, Piotra I - 1872, Jarosława Mądrego - 1890, pomnik Katarzyny II w Wilnie z 1902 r., który wywołał ostre protesty polskiego społeczeństwa). Rzeźby prezentowane w Paryżu były refleksem filozoficznych i religijnych przemyśleń artysty rozdartego między tradycją żydowską a egzystencją w nowym, nieżydowskim świecie. Rzeźbę Pax interpretowano jako odpowiedź na coraz gwałtowniej wzmagające się nastroje antysemickie w Europie.

Liebekowa, korespondentka „Bluszczu”, zaznacza, że spośród 28 rzeźbiarzy rosyjskich każdy wystawiał po kilkanaście dzieł:

i tak rzeźb Antokolskiego jest przeszło dwadzieścia, z których statuy Piotra Wielkiego, Aleksandra II-go i III-go, biusty panującej Pary Cesarskiej, wreszcie Spinoza i Ermak zasługują na wyróżnienie [pisownia oryginalna - E.J.] ${ }^{17}$.

15 B. Guinaudeau, op. cit., s. 48.

16 Por. J. Malinowski, Malarstwo i rzeźba Żydów Polskich w XIX i XX w., Warszawa 2000, s. $22-25$.

17 D. Liebekowa, Z wystawy Paryskiej, „Bluszcz” 1900, nr 28, s. 231. 
Obraz Nikołaja Dubovskiego (1859-1918) Cisza z 1890 r. zachwycił wyobrażeniem natury symbolizującej ludzkie nastroje i namiętności. Porzucając sztafaż i ograniczając paletę barw, Dubovski namalował pejzaż ukazujący naturę w jej pierwotnej, nietkniętej działaniem człowieka formie. Krajobraz jest tu skondensowanym symbolem ludzkiego losu, stanu myśli, tęsknot i lęków. Artysta, stosując monochromatycznie niemal zestrojoną harmonię kolorów, zatrzymał w ramie obrazu dziewiczy obraz natury jako wyobrażenie utraconego raju. Symbolistyczne malarstwo N. Dubovskiego nie operuje „symbolami”, lecz elementami plastycznymi najtrafniej „opowiadającymi” treść, której nie sposób „opowiedzieć”. W tak odczuwanej naturze Arthur Schopenhauer widział

smak, swobodę, naturalną grację i niewymuszone zestawienia jako znaki, że nie wyrosła pod rózgą wielkiego egoisty, lecz władała tu wedle swej woli.

Tak pojmowali symbol krajobrazowy, obok działających we Francji Paula Gauguina (1848-1903), Émile Bernarda (1868-1941), Paula Sérusiera (1864-1927), także James McNill Whistler (1834-903), Edvard Munch (1863-1944) czy Giovanni Segantini (1858-1899).

Anglicy pozostali wierni kunsztowi artystów ideowo i twórczo wywodzących się ze wspaniałej tradycji Arts and Crafts i owego szczególnie intensywnego odczuwania natury, tak znamiennego dla Williama Morrisa (1834-1896). Przedstawiono dzieła, których tematyka odnosiła się do narodowych mitów i legend. Edward Burne-Jones (1833-1898), jeden z czołowych przedstawicieli prerafaelityzmu, wystawił obraz przedstawiający Lancelota w kaplicy Świętego Graala, będący ilustracją legend arturiańskich. W ramach prezentacji sztuki z Wielkiej Brytanii przeważały dzieła z okresu jej dominacji, tzn. z XVIII i początku XIX w. Eksponowano prace dobrze znanych osiemnastowiecznych portrecistów: sir Joshuy Reynoldsa (1723-1792), Thomasa Gainsborougha (1727-1788), Johna Hoppnera (1758-1810), George'a Romneya (1734-1802) i sir Henry'ego Raeborna (1756-1823). Pośród pejzażystów nie mogło zabraknąć tak uznanych artystów jak William Turner (1775-1862) i John Constable (1776-1837). Malarstwo rodzajowe reprezentował George Morland (1763-1804). Tymczasem uwagę zwiedzających skupiła grupa sześciu gobelinów Święty Graal, zaprojektowanych przez E. Burne’a-Jonesa, które zostały zamówione przez Williama Knoxa D’Arcy do jadalni domu Stanmore Hall. Tapiserie zostały wykonane w manufakturze Morris and Co. w $1890 \mathrm{r}$.

Niewątpliwie polityczny wymiar miała skromna wystawa towarzysząca sekcji amerykańskiej, poświęcona twórczości artystów reprezentujących społeczność afroamerykańską Stanów Zjednoczonych, nazwana „Negro 
Exposition / American Negro Exhibit”. Jej komisarzem był Thomas J. Calloway - czarnoskóry działacz na rzecz równouprawnienia ludności murzyńskiej w Ameryce Północnej ${ }^{18}$. Wystawa „American Negro Exhibit” została zorganizowana w niewielkim białym pawilonie wydzielonym $\mathrm{z}$ amerykańskiego. Pokazano przede wszystkim fotografie autorstwa Frances „Fannie” Benjamin Johnston (1864-1952) ${ }^{19}$ wraz z opisami, przedstawiające czarnoskórą ludność zamieszkującą południowe stany Ameryki, manufaktury, periodyki, materiały edukacyjne, książki i mapy. Prezentowane obiekty i sama wystawa miały zaświadczać o postępującym procesie równouprawnienia ludności, jej emancypacji, przedstawić Amerykę jako kraj pragnący wejść w nowe stulecie po wprowadzeniu radykalnych reform społecznych i ekonomicznych ${ }^{20}$.

Antoni Potocki na łamach „Tygodnika Ilustrowanego” oceniał dzieła artystów amerykańskich jako niedopracowane, amatorskie, zdominowane przez

niezliczoną liczbę kobiet uprawiających martwą naturę (ser i owoce), i gdzie Jankes rodzaju męskiego niechętnie rzuca business dla malarstwa, jeśli zaś porzuca, to uprawia na pewno - pejzaż morski ${ }^{21}$.

Japończycy, gotowi przyjąć konwencje kultury i sztuki europejskiej, zdawali sobie sprawę, że narodowa sztuka japońska w stylu nihongo powinna być obecna i że kultywowana tradycja będzie podstawą obecności Kraju Kwitnącej Wiśni w dominującej w świecie kulturze europejskiej. Hayashi uważał, że japońska tradycja malowania na jedwabiu, tematyka tych przedstawień, przekazywanie kolejnym pokoleniom artystów tajników kunsztu przyczyni się do wzbogacenia sztuki europejskiej, a Japończykom pozwoli zachować ich narodową i kulturową tożsamość oraz utrwalić świetność dorobku przodków.

18 Thomas. J. Calloway (?-1930) był wybitnym prawnikiem, dziennikarzem, jednym z pierwszych aktywistów na rzecz praw ludności afroamerykańskiej. Był także wiceprezydentem i generalnym zarządcą Lincoln Land Improvement Company.

${ }^{19}$ Frances Benjamin Johnston (1864-1952) była jednym z pierwszych fotografików i fotoreporterów amerykańskich; studiowała m. in. w Académie Julian w Paryżu.

${ }^{20}$ Por. USA: 1900 Commission to the Paris Exposition, United States, [w:] Catalogue of Exhibitors in the United States Sections of the International Universal Exposition, red. Exposition universelle internationale, Paris 1900, s. 468; T.J. Calloway, US, Commission to the Paris Exposition of 1900, The America Negro Exhibit, Washington DC, 21.12.1889, Carver Papers, Reel 2; Anonim, Negro Exhibit at Paris, „New York Times”, 3.11.1899.

${ }^{21}$ A. Potocki, Sztuka na wystawie paryskiej, „Tygodnik Ilustrowany” 1900, nr 36. 
Przegląd dzieł, które pokazano na wystawie powszechnej w 1900 r., wskazuje, jak istotny dla poszczególnych krajów był aspekt narodowy, na przełomie wieków kształtowany przez potrzebę umocnienia tożsamości narodowych dla jednych, walki o odzyskanie niepodległości dla drugich czy utrwalenia swej niedawno zdobytej niezależności dla kolejnych nacji. Dzieło sztuki stało się zwierciadłem dążeń politycznych, przekonania o własnej mocarstwowości, wyrazem pragnienia, by włączyć się w aktualne, nowoczesne działania ówczesnego świata. Wciąż żywa i bliska sprawie niepodległości Polski była kwestia irlandzka i grecka, o niezawisłość walczyły narody Półwyspu Bałkańskiego, Włosi cieszyli się niepodległością zaledwie od 1861 r., Francuzi wciąż w pamięci mieli wojnę z Prusami.

Problemy narodowościowe angażowały zatem myśli oraz serca artystów i ta kwestia zapewne była powodem powstawania dzieł wzniosłych, ale mogła być także przyczyną ograniczenia i zawężenia perspektywy. Dociekania artystyczne par excellence - wobec powinności narodowych - wydawały się czasami nieistotne bądź odsuwano je na drugi plan. Impresjonistycznie czy symbolistycznie namalowany pejzaż bywał refleksem historii i świadomości politycznej twórcy; miał ukazywać piękno, trud życia i losy ludzi zamieszkujących dane ziemie. Pokazanie dzieła na powszechnej wystawie w kulturalnej stolicy świata było także swego rodzaju demonstracją polityczną. Szczególna rola przypadła artystom polskim reprezentującym w Paryżu państwa zaborcze.

W 1897 r. w Paryżu powstało Koło Polskie Artystyczno-Literackie, którego sekretarzem był Antoni Potocki (1867-1939), pisarz i krytyk literacki, ambasador kultury polskiej we Francji. Podstawowym zadaniem Koła było organizowanie życia kulturalnego Polonii mieszkającej w Paryżu oraz piecza nad nim. Z inicjatywy literatów, działaczy politycznych, dziennikarzy, krytyków, a także artystów mieszkających we Francji urządzano konferencje, prelekcje i spotkania z polskimi pisarzami, koncerty, wieczory dyskusyjne, zajmowano się publikacjami zbiorów polskiej poezji, albumów pamiątkowych (wydano np. album ku czci Fryderyka Chopina i zbiór pieśni polskich w wersji francuskiej w 1899 r.). Sekcja artystyczna utworzona została w 1898 r. jako jedna z gałęzi działalności Koła. Najważniejszym zadaniem wobec zbliżającej się wystawy światowej w 1900 r. było zorganizowanie pawilonu sztuki polskiej. Ze sprawozdania zarządu Koła z 1901 r. 
dowiadujemy się o niepowodzeniu planu zgromadzenia dzieł w jednym miejscu $^{22}$.

Nie mógł być zrealizowany [plan] z powodów politycznych i administracyjnych: regulamin wystawy światowej pozwalał na urządzenie osobnych sekcji tylko i wyłącznie w przypadku państw, które brały w niej oficjalny udział

- pisze Ewa Bobrowska-Jakubowska, powołując się na tekst sprawozdania z 1889 r. (s. 5). Polacy nie uzyskali nawet zezwolenia na przedstawienie swych dzieł w sekcji międzynarodowej ${ }^{23}$.

Katalog wszystkich dzieł artystów narodowości polskiej wystawiających na wystawie powszechnej, rozproszonych po pawilonach trzech państw zaborczych oraz w sekcji międzynarodowej, gdy artyści mieszkali we Francji, Włoszech czy w innych państwach, miał złagodzić decyzję, która była decyzją polityczną. Przypomnijmy nadzieje, jakie Francja pokładała wówczas w sojuszu francusko-rosyjskim, wykluczającym tak demonstracyjną postawę Polaków w ich dążeniach niepodległościowych na wystawie odbywającej się w Paryżu.

Autorka książki Artyści polscy we Francji w latach 1890-1918 przytacza fragment wypowiedzi Léona Gredera, francuskiego krytyka, który przy okazji sprawozdań z wystawy światowej wyraził solidaryzującą się z Polakami postawę:

Polska nie jest rosyjska ani w zakresie jej malarstwa, ani w żadnym innym, nie jest też niemiecka. Jest i pozostanie łacińska, ponieważ jest i pozostanie polska. Można rozproszyć lud, można zmienić kolory jego flagi, uniformy jego celników, zmienić granice polityczne, ale nie zmieni się jego moralności ani religii, dopóki lud ten chce zachować tożsamość. Będzie się zawsze mówiło po polsku w Warszawie, po francusku w Metzu, po włosku w Trieście, wbrew carom, Bismarckom i wszystkim traktatom świata. Czy to oznacza, że jest polska sztuka? Nie. Widzieliśmy, że naród ma sztukę tylko wtedy, kiedy jest wolny. Artyści polscy rozproszeni po całej Europie należą do rozmaitych szkół, a to, co ich charakteryzuje, to właśnie brak charakteru, ponieważ czerpią od wszystkich, nie pozostając $w$ tyle, brakuje im jedynie spójności i jedności, by utworzyć odrębną szkołę ${ }^{24}$.

${ }^{22}$ Sprawozdanie zarządu Koła Polskiego Artystyczno-Literackiego w Paryżu za 1900 roku (istnienia Towarzystwa rok czwarty), Paryż 1901; Variétés artistiques, „Bulletin polonais” 1900, nr 147, s. 315-316.

${ }^{23}$ E. Bobrowska-Jakubowska, Artyści polscy we Francji w latach 1890-1918, Warszawa 2004, s. 81.

${ }^{24}$ L. Greder, Loisirs d'art. Mélanges. La peinture étrangère à l'Exposition de 1900 à Paris, Paris 1901, s. 151, cyt. za: E. Bobrowska-Jakubowska, op. cit., s. 81. 
Niemożliwość zorganizowania pawilonu, w którym można by zademonstrować światu polską sztukę w całości, została zrekompensowana wydaniem przez Koło Polskie Artystyczno-Literackie katalogu dzieł wszystkich artystów narodowości polskiej prezentujących prace na wystawie powszechnej w ramach ekspozycji trzech państw zaborczych. Catalogue des artistes polonaise à l'Exposition internationale universelle de 1900 à Paris. Avec deux plans indiquant la disposition de sections étrangères dans le grand Palais des Beaux-Arts; édité par Société poloniaise artistique et littéraire de Paris zawierał dwa plany wystaw wskazujące rozlokowanie sekcji zagranicznych w Grand Palais, spis dzieł Polaków według sal oraz alfabetyczną listę artystów $^{25}$. Skromna broszura z okładką w barwach narodowych była jedyną udaną publiczną manifestacją polskiej obecności na wystawie powszechnej w 1900 r., stanowiła wyraz dążeń do zjednoczenia Polaków, wskazania wspólnoty ich działań mimo przeciwności politycznych i historycznych. Bobrowska-Jakubowska przypomina niewielką retrospektywną wystawę malarstwa polskiego w Paryżu w 1900 r. urządzoną przez Cypriana Godebskiego (1835-1909). Wystawę otwarto 1 kwietnia w Galerie Georges Petit, pokazano ok. 100 obrazów wypożyczonych od prywatnych kolekcjonerów. Dzieła pochodziły z lat 1800-1900. Celem organizatorów była prezentacja polskiego malarstwa w XIX w. od Aleksandra Orłowskiego (1777-1832), Piotra Michałowskiego (1800-1858), Artura Grottgera (1837-1867), Jana Matejki (1838-1893), Juliusza Kossaka (1824-1898), Henryka Rodakowskiego (1823-1894), Aleksandra Gryglewskiego (1833-1879), Kazimierza Pochwalskiego (1855-1940), poprzez Józefa Chełmońskiego (1850-1914), Aleksandra (1849-1901) i Maksymiliana (1846-1874) Gierymskich, po malarzy mieszkających w Paryżu: Teofila Kwiatkowskiego (1809-1890), Józefa Szermentowskiego (1833-1876), Annę Bilińską (1857-1893); artystów związanych ze środowiskiem monachijskim: Alfreda Wierusz-Kowalskiego (1849-1915) i Józefa Brandta (1841-1915). Pokazano także obrazy najmłodszej generacji malarzy: Olgi Boznańskiej (1865-1940), Józefa Pankiewicza (1866-1940), Ignacego Łopieńskiego (1865-1944), Leokadii Ostrowskiej (1875?-1952).

Wystawa niestety nie została dobrze przyjęta zarówno przez krytyków polskich, jak i francuskich. Jej twórcom zarzucano nadmierne wyeksponowanie artystów starszego pokolenia oraz brak jasnych kryteriów doboru prac, co zaowocowało wystawieniem obrazów słabych, niedających rzeczywistego wglądu w polską sztukę mijającego stulecia. Wystawa nie wzbudziła zainteresowania Francuzów, a miejscowa prasa, poza pojedynczymi głosami, nie odnotowała jej.

${ }^{25}$ Catalogue des artistes polonaise à l'Exposition internationale universelle de 1900 à Paris. Avec deux plans indiquant la disposition de sections étrangères dans le grand Palais des Beaux-Arts, red. Société poloniaise artistique et littéraire de Paris, Paris 1900. 
Można sądzić, że małe zainteresowanie ekspozycją Polaków wobec nadmiaru innych atrakcji oferowanych widzom w trakcie trwania wystawy powszechnej $1900 \mathrm{r}$. było spowodowane jej lokalnym charakterem, zapewne skromnym źródłem finansowania (organizatorzy nie dysponowali funduszem oficjalnym), co z kolei sprawiło, że zabrakło fachowców, którzy dokonaliby wyboru dzieł i odpowiednio je zaprezentowali. Wedle komentarza dotyczącego wystawy w galerii Georges’a Petita, zamieszczonego w „Bulletin polonais", prace zostały pożyczone od prywatnych kolekcjonerów, zatem nie zawsze musiały mieć wartość muzealną ${ }^{26}$.

Polacy chcą udowodnić, że ich naród, nawet jeśli wydarto mu w tym stuleciu wszelkie prawa, nie stał się jednak ani rosyjski, ani austriacki, ani pruski, utracił jedynie osobowość polityczną. [...] kolekcjonerzy, którzy zechcieli udostępnić komitetowi wystawy zespół dzieł polskich malarzy naszego wieku, dali okazję do zamanifestowania, że w dziedzinie sztuk plastycznych Polska także stworzyła dzieła, które świadczą o jej narodowej żywotności ${ }^{27}$.

Niepowodzenie wystawy, surowa krytyka, brak uznania dla działalności sekcji artystycznej w 1900 r., zapewne także rezygnacja Cypriana Godebskiego z funkcji prezesa Koła sprawiły, że sprawy dotyczące sztuk plastycznych zostały odłożone na rok następny.

Udział artystów polskich w ramach wystaw zorganizowanych przez kraje, które reprezentowali, pozostał zatem propozycją warunkującą ich uznanie, nagrody, uczestnictwo w międzynarodowym życiu artystycznym.

Największym sukcesem Polaków były dwa złote medale wręczone przedstawicielom Austrii wystawiającym w Pawilonie Secesji: Józefowi Mehofferowi (1869-1946) za obraz olejny Śpiewaczka. Portret Wandy Janakowskiej (1896) i projekt do witraża Męczennicy (1889), wykonany dla gotyckiej kolegiaty pod wezwaniem św. Mikołaja w szwajcarskim Fryburgu, oraz drzeworytnikowi Feliksowi Stanisławowi Jasińskiemu (1862-1901) - za serię składającą się z pięciu prac graficznych. Ten ostatni reprezentował Francję.

Niemal wszystkie biografie ówczesnych artystów zawierają daty ich studiów bądź pobytu w Paryżu, który w czasach Drugiego Cesarstwa koncentrował najważniejsze instytucje artystycznego życia Francji. Nowoczesne miasto, jakim stał się Paryż przebudowany i przekształcony przez barona Georges'a-Eugèna Haussmanna (1809-1891), szczyciło się instytucjami

${ }^{26}$ Variétés artistiques, „Bulletin poloniais” 1900, nr 141, s. 109. Cyt. za: E. Bobrowska-Jakubowska, op. cit., s. 83.

27 Ibidem. 
o międzynarodowym prestiżu, by wymienić: Instytut Francji, Szkołę Sztuk Pięknych, Luwr, regularnie odbywające się Salony, liczne galerie sztuki, marszandów i kolekcjonerów. Stolica Francji w XIX w. była miejscem, gdzie wydawano największą liczbę książek i dzienników na temat sztuki; jak magnes przyciągały publiczność sceny Opery Paryskiej, teatry i kabarety. Młodzi twórcy z niemal wszystkich zakątków świata przyjeżdżali do Paryża - oczywiście nie zabrakło wśród nich Polaków, dla których Francja często stawała się miejscem przeznaczenia, symbolem wolności duchowej i twórczej.

$$
* * *
$$

U progu XX w. obok powszechnie panującego - jak się wówczas wydawało - historyzmu i akademizmu toruje sobie drogę to wszystko,

co nazywano od kilkunastu lat różnie: jedni dekadentyzmem, inni młodą sztuką, nową sztuką, stylem młodym, nowym, nowoczesnym, modernizmem ${ }^{28}$

- pisał przed laty Mieczysław Porębski. I jeszcze fin de siècle jako finalna forma tamtej epoki. Dziewiętnastowieczny modernizm swe korzenie miał w narastającym poczuciu nadchodzącego kryzysu kultury europejskiej, formowanej od renesansu w przekonaniu, że ludzkość, a z nią cały świat zracjonalizowany, podporządkowany umysłowi człowieka, zmierza ku nieuchronnej katastrofie.

W ciągu XIX w. stało się jasne, że rozwój nauki, techniki, przemysłu, nagromadzenie bogactw nie rozwiązują starych konfliktów, ale rodzą nowe, niosą wyniszczenie biologiczne i moralne, które skrupulatnie odnotowała naturalistyczna powieść i krytycznie nastawione do rzeczywistości społecznej ilustracyjno-dydaktyczne malarstwo. W warunkach, w których wszystko zaczynało wydawać się dwuznaczne, zatęchłe, zabrudzone, potrzeba odnowienia, oczyszczenia, powrotu do jakiegoś niejasnego, zmitologizowanego początku, zaczynała być odczuwana mocniej niż kiedykolwiek ${ }^{29}$.

Wiek XX nie ocalił owej potrzeby odnowienia, „powrotu do źródeł”, oczyszczenia, głoszonej przez modernistów w XIX w., przeczuwających niejako nadchodzący czas chaosu, ruiny, przegranej człowieka. Obraz niekończącego się postępu świata, którego wcieleniem miała być Powszechna Wystawa Światowa w Paryżu w 1900 r., na zawsze stracił swą moc w obliczu

${ }^{28}$ M. Porębski, Modernizm i modernizmy, [w:] Sztuka około 1900 roku. Materiały Sesji Stowarzyszenia Historyków Sztuki. Kraków, grudzień 1967, Warszawa 1969, s. 40.

${ }^{29}$ Ibidem, s. 41. 
wydarzeń Wielkiej Wojny. Okazała się ona tragicznym w swych skutkach spektaklem śmierci i zaczynem katastrofy drugiej wojny światowej.

Ideologie końca XIX i początku XX w. nie dały odpowiedzi na pytanie o sens ludzkiego życia ani nie rozstrzygnęły nurtującego problemu poczucia „końca czasu” i jego paradoksalnego związku z nieskończonością, prawdą i naturą, a to - zdaniem ówczesnych - warunkowało potrzebę powrotu do źródeł: do natury, do początków dziejów człowieka. Tych początków poszukiwano w mitach i podświadomości, w których miała zachować się pamięć o źródłach niepodzielnej całości świata - ducha i materii, człowieka i przyrody.

\section{BIBLIOGRAFIA}

Anonim, Negro Exhibit at Paris, „New York Times”, 3.11.1899.

Bobrowska-Jakubowska E., Artyści polscy we Francji w latach 1890-1918, Warszawa 2004.

Callowey T. J., US, Commission to the Paris Exposition of 1900, The America Negro Exhibit, Washington DC, 21.12.1889, Carver Papers, Reel 2.

Catalogue des artistes polonaise à l'Exposition internationale universelle de 1900 à Paris. Avec deux plans indiquant la disposition de sections étrangères dans le grand Palais des BeauxArts; édité par Société poloniaise artistique et littéraire de Paris, red. Société poloniaise artistique et littéraire de Paris, Paris 1900.

Catalogue of Exhibitors in the United States Sections of the International Universal Exposition, red. Exposition universelle internationale, Paris 1900.

Greder L., Loisirs d'art. Mélanges. La peinture étrangère à l'Exposition de 1900 à Paris, Paris 1901.

Guinaudeau B., La Décennale russe, „L'Aurore”, 27.07.1900.

Król W., Między realizmem a symbolizmem. Twórczość Akseli Gallen-Kalleli, http://www. kul.pl/files/564/public/ARTykuly/ARTykuly003/ARTykuly_003_2009_WK_23str.pdf (dostęp: 19.01.2016).

Liebekowa D., Z wystawy Paryskiej, „Bluszcz” 1900, nr 28, s. 231.

Lönnrot E., Kalevala, tłum. J. Litwiniuk, Warszawa 1998.

Malinowski J., Malarstwo i rzeźba Żydów Polskich w XIX i XX wieku, Warszawa 2000.

Porębski M., Modernizm i modernizmy, [w:] Sztuka około 1900 roku. Materiały Sesji Stowarzyszenia Historyków Sztuki. Kraków, grudzień 1967, Warszawa 1969.

Potocki A., Sztuka na wystawie paryskiej, „Tygodnik Ilustrowany” 1900, nr 36.

Rosenblum R., Stevens M.A., Dumas A., 1900. Art at the Crossroads, 16 January - 3 April 2000 [katalog wystawy, Solomon R. Guggenheim Museum], New York 2000.

Sarajas-Korte S., Lumière du Nord [katalog wystawy, Petit Palais], Paris 1987.

Sprawozdanie zarządu Koła Polskiego Artystyczno-Literackiego w Paryżu za 1900 roku (istnienia Towarzystwa rok czwarty), Paryż 1901. 
Tuchman B.W., Wyniosła wieża. Świat przed pierwsza wojną światowa 1890-1914, tłum. J. Zawadzka, Warszawa 1966.

Wageman P., Fired by Passion. The life and work of Akseli Gallen Kallela, [w:] Akseli Gallen-Kallela. The spirit of Finland, red. D. Jackson, P. Wageman, Rotterdam 2007, s. 10-21.

Variétés artistiques, „Bulletin poloniais” 1900, nr 141, s. 109.

Variétés artistiques, „Bulletin polonais” 1900, nr 147, s. 315-316.

Varnedoe K., Northern Light, New Haven, London 1988.

\section{SUMMARY}

\section{Passion of spirituality or national art. The 1900 Universal World Exhibition in Paris}

A review of the works which were displayed at the Exposition of the Decade (Grand Palais) indicates how essential the national aspect was for individual countries - an aspect shaped at the turn of the century by such factors as the need to strengthen national identity for some, the fight for independence for others, and the consolidation of newly-gained independence for yet other nations. A work of art became a mirror of political aspirations, of a conviction concerning the status of one's own nation as a superpower, and an expression of the desire to became involved in the current, modern activities of the world at the time.

The 1900 exposition was a parade presenting a utopian vision of universal harmony among nations and states. In the $19^{\text {th }}$ century, there ensued an explosion of the quest for and rediscovery of national identifications, of the battle for independence on the part of the nations absorbed by economically and militarily powerful states, of world colonization and of aggressive Eurocentrism. Nationalistic moods accompanied artists who came from countries fighting for their independence, as well as those who represented states enjoying a stable geopolitical situation.

There were a large number of Poles displaying their works at the exposition; they represented mainly the Russian and Austrian section - as part of those sections, they obtained separated 'Polish' rooms. There was no question of any joint representation of art from the two Partitions, for the reservations of the Partition states were very strong. The Poles' greatest successes were two gold medals awarded to two artists: Józef Mehoffer and Feliks Stanisław Jasiński. 